\title{
The Effects of Microwave Pretreatment of Dairy Manure on Methane Production
}

\author{
Ian Chan ${ }^{1}$, Asha Srinivasan ${ }^{1}$, Ping H. Liao ${ }^{1}$, Kwang V. Lo ${ }^{1 *}$, Donald S. Mavinic ${ }^{1}$, Jim Atwater ${ }^{1}$, \\ James R. Thompson ${ }^{2}$
}

${ }^{1}$ Department of Civil Engineering, University of British Columbia, Vancouver, Canada; ${ }^{2}$ Dairy Education and Research Centre, University of British Columbia, Vancouver, Canada.

Email: *kvlo@civil.ubc.ca

Received February $1^{\text {st }}, 2013$; revised May $6^{\text {th }}, 2013$; accepted May $24^{\text {th }}, 2013$

Copyright (C) 2013 Ian Chan et al. This is an open access article distributed under the Creative Commons Attribution License, which permits unrestricted use, distribution, and reproduction in any medium, provided the original work is properly cited.

\begin{abstract}
This study was undertaken to evaluate the efficiency of a liquid-solids separation process and microwave pretreatment, as well as anaerobic biodegradability of microwave pretreated dairy manure. Liquid-solids separation of raw dairy manure resulted in solid and liquid fractions having different properties, with the solid fractions richer in total and volatile solids content and liquid fractions richer in nutrients and metal ions. Substantial amounts of soluble chemical oxygen demand and nutrients were released into the solution after the microwave treatment. The microwave pretreated dairy manure was also subjected to anaerobic digestion. The kinetic parameters of methane production potential, maximum methane production rate and lag time were determined using the modified Gompertz equation. Anaerobic digestion of liquid manure, without microwave treatment, outperformed the sets with microwave treatment. The microwave-treated liquid dairy manure, without acid addition had better results in terms of methane potential and methane production, than with acid addition. Thermophilic digestion exhibited a higher maximum methane production rate than that of mesophilic digestion, but lower methane yields. The microwave pretreatment of dairy manure resulted in high soluble chemical oxygen demand; however, methane yield was not increased.
\end{abstract}

Keywords: Liquid-Solids Separation; Microwave Treatment; Anaerobic Digestion; Methane Production

\section{Introduction}

Anaerobic digestion is a technology widely used for treatment of organic waste for methane production. Its use for treating dairy manure can provide a source of energy, and alleviate environmental concerns on a dairy farm. The digester effluent retains nitrogen $(\mathrm{N})$ and phosphorus $(\mathrm{P})$ of dairy manure, which maintains its value as a fertilizer supplement. However, dairy manure contains very high suspended solids, and has low anaerobic biodegradability. A mechanical liquid-solids separation process, resulting in a separated liquid fraction with much less suspended solids, can remove most of fibrous solids in dairy manure. This will allow the anaerobic digester to be operated at a shorter hydraulic retention time (HRT) or a higher loading rate [1]. Lo et al. [2] conducted mesophilic anaerobic digestion of unscreened and screened manure, after liquid-solid separation, for the same organic loading rates at 16 days hydraulic retention time;

${ }^{*}$ Corresponding author. liquid-solids separation had a minimal effect on the rate of methane production. For shorter HRTs, a significant increase was found in methane production rate for the screened manure over unscreened manure. The screened dairy manure was also used as feed material for a fixedfilm reactor; a very high methane volumetric production rate was produced when the digester was operated at very short HRTs, as low as $3 \mathrm{~h} \mathrm{[3].}$

Screened manure had a higher anaerobic biodegradeability in comparison to unscreened manure, because biodegradable suspended solids content (SS) larger than mesh openings $(1 \mathrm{~mm})$ were removed [4]. Even though a considerable amount of SS was in screened dairy manure, only a small fraction of its chemical oxygen demands (COD) was in soluble form, additional treatment for enhancing biodegradability would be desirable. Separation of solids and liquid fractions of dairy manure by means of screening and coagulation-flocculation resulted in most of organic matter in soluble form in liquid fraction [4]. The methane production rate for the treated liquid frac- 
tion was higher than for dairy manure or screened manure. Also, the liquid fraction treated by coagulationflocculation, would be amenable to treatment in high loading anaerobic digesters, operated at shorter HRTs. The liquid fraction free of suspended solids was treated at $35^{\circ} \mathrm{C}$ in an upflow anaerobic sludge blanket reactor operating at an organic rate of $40.8 \mathrm{~g} \mathrm{COD} / \mathrm{L} \cdot \mathrm{d}$ (chemical oxygen demand per liter reactor per day) and reaching a methane production rate of $10.3 \mathrm{~L} \mathrm{CH}_{4} / \mathrm{L} \cdot \mathrm{d}$ (litre methane per litre reactor per day). The higher methane volumetric production rate was obtained for the treated liquid fraction, than a conventional anaerobic digester treating either unscreened or screened manure.

A microwave enhanced advanced oxidation process $\left(\mathrm{MW} / \mathrm{H}_{2} \mathrm{O}_{2}-\mathrm{AOP}\right)$ proved to be an efficient pretreatment process for solids solubilization and nutrient release, for various organic wastes. This process uses microwave irradiation, in combination with hydrogen peroxide, to generate hydroxyl radicals to react with organic waste. As a result, the SS content is reduced and a higher soluble COD in the resulting solution is obtained [5-8]. The SCOD content in the treated solution depends on the microwave temperature, hydrogen peroxide dosage, and reaction period. High microwave temperatures, as well as a higher hydrogen peroxide dosage resulted in very high SCOD concentration in the treated solution. Up to $90 \%$ of TCOD was in the soluble form. Kenge et al. [6] reported that for treating dairy manure, substantial quantity of nutrients of nitrogen and phosphorus, and moderate SCOD concentration were attained in the treated solution at a $\mathrm{pH}$ of 3.5. At neutral and basic conditions, significant amounts of volatile fatty acids (VFA) and SCOD were obtained; however, there was no significant phosphate release at all.

Previous studies focused on solubilization of solids and nutrient release from dairy manure; anaerobic biodegradability of dairy manure, after the $\mathrm{MW} / \mathrm{H}_{2} \mathrm{O}_{2}$-AOP treatment, had not yet been conducted in our laboratory. The current study was undertaken to evaluate the efficiency of liquid-solids separation process of dairy manure, to characterize effluent from the microwave treated dairy manure, and to determine anaerobic biodegradability of the post-microwave treated dairy manure. It was designed to validate a hypothesis that high SCOD obtained from microwave pretreatment (MW) would increase the anaerobic biodegradability of dairy manure.

\section{Materials and Methods}

\subsection{Experimental Procedures}

\subsubsection{Liquid-Solids Separation Process}

Raw dairy manure and liquid dairy manure for laboratory and field studies were obtained from the UBC Dairy Research and Education Center in Agassiz, British Columbia, Canada. Three sets of raw manure samples, each with three replicate, at different ratios of dilution were prepared; they were no dilution, one part of manure to one part of water (w/w), and two parts of manure to one part of water (w/w). A US No. 10 size sieve, which has $1.99 \mathrm{~mm}$ openings, was used in this laboratory study. The solid fractions were diluted with distilled water and mixed at $130 \mathrm{rpm}$ for one hour, with a laboratory shaker, to facilitate extraction of nutrients and metals.

\subsubsection{Microwave Pretreatment}

The dairy manure used in the MW study is the liquid portion obtained after liquid-solids separation from the manure pit. Four sets of microwave experiment were conducted: microwave only (MW), microwave with hydrogen peroxide $\left(\mathrm{MW} / \mathrm{H}_{2} \mathrm{O}_{2}\right)$, microwave with acid $\left(\mathrm{MW} / \mathrm{H}^{+}\right)$, microwave with hydrogen peroxide and acid $\left(\mathrm{MW} / \mathrm{H}^{+} / \mathrm{H}_{2} \mathrm{O}_{2}\right)$. A hydrogen peroxide solution was introduced with the manure sample simultaneously into the microwave unit. The dosage of hydrogen peroxide was set at $0.3 \%$ for the $\mathrm{MW} / \mathrm{H}_{2} \mathrm{O}_{2}$ and $\mathrm{MW} / \mathrm{H}^{+} / \mathrm{H}_{2} \mathrm{O}_{2}$ sets. For the $\mathrm{MW} / \mathrm{H}^{+} / \mathrm{H}_{2} \mathrm{O}_{2}$ set, the manure sample was adjusted to $\mathrm{pH}$ 3.5. All experimental sets, except the untreated manure, were subjected to pilot-scale, continuous-flow microwave treatment at a flow rate of $0.5 \mathrm{~L} / \mathrm{min}$ under microwave power of $6 \mathrm{~kW}$, and an effluent temperature of around $96^{\circ} \mathrm{C}$.

\subsubsection{Anaerobic Biodegradability}

Anaerobic biodegradability of both untreated and the microwave treated liquid dairy manure was tested at mesophilic temperature $\left(35^{\circ} \mathrm{C} \pm 1{ }^{\circ} \mathrm{C}\right)$ and thermophilic temperatures $\left(55^{\circ} \mathrm{C} \pm 1{ }^{\circ} \mathrm{C}\right)$, in a batch operation mode. Five experiment sets, each with five replicate, were conducted; there were untreated manure (no microwave treatment), $\mathrm{MW}, \mathrm{MW} / \mathrm{H}^{+}, \mathrm{MW} / \mathrm{H}_{2} \mathrm{O}_{2}$, and $\mathrm{MW} / \mathrm{H}^{+} / \mathrm{H}_{2} \mathrm{O}_{2}$.

An inoculum of $10 \mathrm{ml}$ was added into $100 \mathrm{~mL}$ of sample in a $150 \mathrm{~mL}$ serum bottle for each set. The acclimated inoculum for mesophilic digestion had the following characteristics: total solids (TS) of $4.3 \% \pm$ $0.31 \%$, volatile solids (VS) of $2.89 \% \pm 0.19 \%$, volatile fatty acids (VFA) of $2874 \pm 190 \mathrm{mg} / \mathrm{L}$, total kjeldahl nitrogen $(\mathrm{TKN})$ of $2032 \pm 389 \mathrm{mg} / \mathrm{L}$ and total phosphorus (TP) of $423 \pm 71 \mathrm{mg} / \mathrm{L}$. For thermophilic digestion, the inoculum had TS of $7.3 \% \pm 0.14 \%$, VS of $4.47 \% \pm 0.87 \%$, VFA of $429 \pm 17 \mathrm{mg} / \mathrm{L}, \mathrm{TKN}$ of $4039 \pm$ $178 \mathrm{mg} / \mathrm{L}$ and TP of $792 \pm 38 \mathrm{mg} / \mathrm{L}$. If adjustment was required for $\mathrm{pH}$ and alkalinity of the set, either sulfuric acid $(30 \%)$ or sodium hydroxide $(12.5 \mathrm{M})$ was used for $\mathrm{pH}$, and $2000 \mathrm{mg} / \mathrm{L}$ of $\mathrm{NaHCO}_{3}$ of alkalinity $\left(\right.$ as $\left.\mathrm{CaCO}_{3}\right)$ was added to the solution. Serum bottles were sealed, and kept in a water bath at set temperatures until they stopped producing biogas. The volume of methane production was reported in norm conditions of $293 \mathrm{~K}$ and 1013 mbar. 


\subsection{Chemical Analysis}

Liquid dairy manure and MW treatment samples were centrifuged at $3500 \mathrm{rpm}$ for 10 minutes, and the supernatant was extracted for analysis of SCOD, orthophosphate, soluble ammonia $\left(\mathrm{NH}_{4}{ }^{+}-\mathrm{N}\right)$, and VFA. All of the chemical analyses followed the procedures outlined in Standard Methods [9]. For orthophosphate analysis (o- $\mathrm{PO}_{4}$ ), dairy manure samples were determined at $0.5 \%$ TS to ensure correct measurement [10]. The initial dairy manure samples were also analyzed for TS, TCOD, TP and TKN. All chemical analyses, except TS, VS, COD, VFA and metals, were determined by a flow injection system, (Lachat Quik-Chem 8000 Automatic Ion Analyzer, Lachat Instruments, USA). A Hewlett Packard 6890 Series II gas chromatograph, equipped with a flame ionization detector (FID), was used to measure VFA. Volatile separation was accomplished with an HP free fatty acid phase column $(0.25 \mathrm{~m} \times 0.31 \mathrm{~mm}$ with $0.52 \mu$ film thickness). The injection temperature was set at $175^{\circ} \mathrm{C}$ and the flame ionization detector was at $250^{\circ} \mathrm{C}$. Helium was the carrier gas at a head pressure of $69 \mathrm{kPa}$. Calcium $(\mathrm{Ca})$, magnesium $(\mathrm{Mg})$, sodium $(\mathrm{Na})$ and potassium $(\mathrm{K})$ were determined using a Varian Spectra 220 Fast Sequential Atomic Absorption Spectrometer.

\section{Results and Discussion}

\subsection{Characteristics of Liquid Fraction and Solids Fraction}

The mass balance and chemical characteristics of liquid- solids separation experiments are listed in Tables 1 and 2. Dairy manure collected straight from the UBC dairy barn had high concentrations of nitrogen, phosphorus, and minerals of $\mathrm{K}, \mathrm{Ca}$, and $\mathrm{Mg}$. About $50 \%$ of the nitrogen and $75 \%$ of potassium were in the liquid portion of dairy manure. About $20 \%$ of total phosphorus was in the soluble form (orthophosphate) in the liquid fraction since most of manure phosphorus was tied up in the solids portion of the manure.

As expected, liquid-solids separation of raw dairy manure resulted in solid and liquid fractions that had different properties; the solid fractions were richer in TS and VS content, while the liquid fractions were richer in nutrients and metal ions. Compared to the initial unseparated manure, separation resulted in a solid fraction having a higher composition of TS, and liquid fractions with higher nutrients and metals. In general, adding a large volume of dilution water resulted in a higher percentage of the liquid fraction; however, it yielded less solids content in the liquid fraction. The SCOD in liquid fraction were $23.4 \pm 4.4,16.8 \pm 32.8$ and $13.9 \pm 0.5 \mathrm{~g} / \mathrm{L}$ for no dilution, two parts of manure to one part of water, and one to one dilution, respectively. In terms of the SCOD/TS ratio, it was higher for one part of manure to one part water dilution (0.58), than for two parts of manure to one part of water $(0.51)$. Rico et al. reported that the higher the percentage of water used for dilution, the higher SCOD/TS ratio was obtained in the liquid fraction. Additional fluid favored the detachment of fineand colloidal solids from long fibers present in the dairy manure [4]. The higher ratio of SCOD/TS in the liquid

Table 1. Mass balance of liquid and solid fraction.

\begin{tabular}{cccccc}
\hline Dilution factor (manure: water) & Total weight (g) & Weight of LS (g) & Weight of SF (g) & LF (\%) & SF (\%) \\
\hline 0 & 1075 & 628 & 447 & 58 & 42 \\
$2: 1$ & 1136 & 599 & 537 & 53 & 47 \\
$1: 1$ & 1246 & 796 & 450 & 64 & 36 \\
\hline
\end{tabular}

$\mathrm{LF}=$ liquid fraction; $\mathrm{SF}=$ solid fraction .

Table 2. Distributions of nutrient in liquid and solids fraction.

\begin{tabular}{|c|c|c|c|c|c|c|c|c|c|c|}
\hline $\begin{array}{c}\text { Dilution } \\
\text { (manure: } \\
\text { water) }\end{array}$ & Sample & $\begin{array}{c}\text { TS } \\
(\%)\end{array}$ & $\begin{array}{l}\text { VS } \\
(\%)\end{array}$ & $\begin{array}{c}\mathrm{Ca} \\
\text { (\% of dry } \\
\text { matter) }\end{array}$ & $\begin{array}{c}\mathrm{Mg} \\
\text { (\% of dry } \\
\text { matter) }\end{array}$ & $\begin{array}{c}\mathrm{K} \\
\text { (\% of dry } \\
\text { matter) }\end{array}$ & $\begin{array}{c}\mathrm{PO}_{4}-\mathrm{P} \\
(\% \text { of dry } \\
\text { matter) }\end{array}$ & $\begin{array}{c}\mathrm{TP} \\
\text { (\% of dry } \\
\text { matter) }\end{array}$ & $\begin{array}{l}\mathrm{NH}_{3}-\mathrm{N} \\
\text { (\% of dry } \\
\text { matter) }\end{array}$ & $\begin{array}{c}\text { TKN } \\
\text { (\% of dry } \\
\text { matter) }\end{array}$ \\
\hline 0 & Manure & $8.0 \pm 0.2$ & $7.5 \pm 0.2$ & $3.67 \pm 0.3$ & $2.69 \pm 0.1$ & $8.73 \pm 1.9$ & $0.2 \pm 0.0$ & $0.8 \pm 0.1$ & $1.8 \pm 0.1$ & $3.4 \pm 0.2$ \\
\hline 0 & LF & $3.57 \pm 0.1$ & $3.40 \pm 0.2$ & $1.52 \pm 0.1$ & $1.83 \pm 0.1$ & $12.18 \pm 1.5$ & $0.11 \pm 0.0$ & $0.84 \pm 0.0$ & $2.38 \pm 0.3$ & $5.04 \pm 0.7$ \\
\hline 0 & SF & $9.98 \pm 1.3$ & $9.66 \pm 1.5$ & $0.67 \pm 0.0$ & $0.39 \pm 0.0$ & $3.90 \pm 0.7$ & $0.12 \pm 0.1$ & $0.52 \pm 0.0$ & $0.87 \pm 0.2$ & $3.33 \pm 0.34$ \\
\hline $2: 1$ & LF & $3.28 \pm 0.2$ & $3.14 \pm 0.2$ & $1.67 \pm 0.0$ & $1.65 \pm 0.1$ & $9.94 \pm 1.2$ & $0.14 \pm 0.0$ & $0.87 \pm 0.1$ & $1.60 \pm 0.1$ & $4.82 \pm 0.5$ \\
\hline $2: 1$ & SF & $8.74 \pm 0.3$ & $8.20 \pm 0.4$ & $0.78 \pm 0.1$ & $0.37 \pm 0.0$ & $3.78 \pm 0.7$ & $0.10 \pm 0.0$ & $0.44 \pm 0.0$ & $0.64 \pm 0.0$ & $2.65 \pm 0.2$ \\
\hline $1: 1$ & LF & $2.39 \pm 0.2$ & $2.28 \pm 0.1$ & $1.36 \pm 0.3$ & $2.20 \pm 0.6$ & $11.3 \pm 1.8$ & $0.22 \pm 0.0$ & $0.92 \pm 0.0$ & $2.04 \pm 0.1$ & $5.28 \pm 0.1$ \\
\hline $1: 1$ & $\mathrm{SF}$ & $8.59 \pm 0.3$ & $8.28 \pm 0.5$ & $0.72 \pm 0.1$ & $0.36 \pm 0.1$ & $4.32 \pm 1.5$ & $0.08 \pm 0.0$ & $0.39 \pm 0.0$ & $0.49 \pm 0.0$ & $2.33 \pm 0.2$ \\
\hline
\end{tabular}

$\mathrm{LF}=$ liquid fraction; $\mathrm{SF}=$ solid fraction. 
fraction might also enhance methane production; however, a higher volume of screened liquid manure needs to be treated. The higher water dilution to manure ratio would, therefore, make it less economically feasible for manure management or anaerobic digestion.

The solids portion after separation, in terms of weight, varied from $36 \%$ to $47 \%$ (Table 1). Even though more than half of TKN (organic nitrogen and ammonia) was dissolved in liquid fractions as ammonia, a significant amount of organic nitrogen remained in the solid fraction, as shown in Table 2. Most of the phosphorus was also retained in the solids portion; the liquid fraction, after the liquid-solids separator, had about $30 \%$ - 35\% of total manure phosphorus, while the solids fraction contained $65 \%-70 \%$.

The overall results also indicated that the dilution with 1:1 (manure: water) was the best for the purpose of both nutrient release and solids solubilization. The TS content of the resulting solution from this laboratory-scale study was closer to the value of the liquid manure collected from the pit, which was between $2 \%$ to $3 \%$ TS.

Due to the set-up of a pilot-scale unit used in this study, such a range of TS concentration was the most suitable for the $\mathrm{MW} / \mathrm{H}_{2} \mathrm{O}_{2}$-AOP treatment. This would make it easier for pumping manure for other treatment processes, such as struvite crystallization for producing fertilizer, anaerobic digestion for bioenergy production, and/or field application.

\subsection{Microwave Treatment}

The results of microwave pretreatment, as well as acid treatment are presented in Table 3. More than $60 \%$ of total phosphorus was released into solution as orthophosphate, with an addition of acid without MW treatment, while the concentration of SCOD decreased. On the other hand, the ratio of VS to TS for acid addition treatment was similar to the initial manure $(63 \%$ versus $66 \%$ ). This may be attributed to chemical reactions between various soluble constituents or agglomeration of fine suspended particles of dairy manure. As a result, the increase in particle size caused precipitation, and a decrease in SCOD concentration. Nonetheless, agglomerated particles would be destroyed after microwave treatment resulting in an increase in SCOD. It shall also be noted that the SCOD values increased, regardless of the MW treatment conditions (Table 3). The ratios of SCOD/TCOD are between $42 \%$ to $45 \%$ for all of the MW treatments.

Substantial amounts of orthophosphates can be released into solution after the microwave treatment [7-9, $11,12]$. In this study, the release of orthophosphate was

Table 3. Results of microwave treatment.

\begin{tabular}{|c|c|c|c|c|c|c|}
\hline & Untreated & $\mathrm{H}^{+}$ & MW & $\mathrm{MW} / \mathrm{H}_{2} \mathrm{O}_{2}$ & $\mathrm{MW} / \mathrm{H}^{+}$ & $\mathrm{MW} / \mathrm{H}^{+} / \mathrm{H}_{2} \mathrm{O}_{2}$ \\
\hline TS $(\%)$ & $3.02 \pm 0.25$ & $3.87 \pm 0.12$ & $2.32 \pm 0.03$ & $2.39 \pm 0.11$ & $2.74 \pm 0.12$ & $3.37 \pm 0.27$ \\
\hline VS (\%) & $2.00 \pm 0.18$ & $2.46 \pm 0.09$ & $1.54 \pm 0.02$ & $1.59 \pm 0.07$ & $1.52 \pm 0.10$ & $2.06 \pm 0.22$ \\
\hline VS/TS (\%) & $66 \pm 6$ & $63 \pm 2$ & $66 \pm 1$ & $67 \pm 3$ & $55 \pm 4$ & $61 \pm 6$ \\
\hline $\operatorname{TCOD}(\mathrm{g} / \mathrm{L})$ & $29.4 \pm 1.65$ & $30.9 \pm 1.56$ & $24.0 \pm 0.60$ & $24.4 \pm 1.35$ & $21.3 \pm 1.71$ & $25.4 \pm 2.91$ \\
\hline $\operatorname{SCOD}(g / L)$ & $9.81 \pm 0.21$ & $7.76 \pm 0.22$ & $10.4 \pm 0.31$ & $11.0 \pm 0.21$ & $8.49 \pm 0.28$ & $10.6 \pm 0.75$ \\
\hline SCOD/TCOD (\%) & $33 \pm 2$ & $25 \pm 1$ & $43 \pm 1$ & $45 \pm 2$ & $40 \pm 3$ & $42 \pm 5$ \\
\hline VFA (mg/L) & $2853 \pm 141$ & $2523 \pm 66$ & $2759 \pm 124$ & $2762 \pm 59$ & $2596 \pm 36$ & $2418 \pm 44$ \\
\hline TP-total (mg/L) & $239 \pm 67$ & $301 \pm 7$ & $233 \pm 2$ & $213 \pm 31$ & $278 \pm 5$ & $231 \pm 82$ \\
\hline TP-soluble (mg/L) & $5 \pm 2$ & $197 \pm 7$ & $13 \pm 1$ & $16 \pm 1$ & $190 \pm 4$ & $200 \pm 5$ \\
\hline $\mathrm{o}-\mathrm{PO}_{4}(\mathrm{mg} / \mathrm{L})$ & $11 \pm 1$ & $182 \pm 6$ & $3 \pm 2$ & $3 \pm 2$ & $195 \pm 4$ & $182 \pm 1$ \\
\hline TKN (mg/L) & $1636 \pm 476$ & $1984 \pm 45$ & $1792 \pm 26$ & $1528 \pm 203$ & $1617 \pm 100$ & $1437 \pm 547$ \\
\hline $\mathrm{NH}_{4}^{+}-\mathrm{N}(\mathrm{mg} / \mathrm{L})$ & $904 \pm 82$ & $1052 \pm 50$ & $748 \pm 27$ & $666 \pm 9$ & $1080 \pm 15$ & $1116 \pm 22$ \\
\hline $\mathrm{pH}$ & 7.6 & 3.55 & 9.3 & 9.4 & 3.55 & 2.7 \\
\hline Soluble $\mathrm{Na}(\mathrm{mg} / \mathrm{L})$ & 474 & 437 & 484 & 444 & 383 & 367 \\
\hline Soluble K (mg/L) & 2428 & 2395 & 2405 & 2285 & 2523 & 2387 \\
\hline Soluble Ca (mg/L) & 2 & 758 & 40 & 50 & 1386 & 1162 \\
\hline Soluble $\mathrm{Mg}(\mathrm{mg} / \mathrm{L})$ & 237 & 460 & 210 & 198 & 509 & 463 \\
\hline
\end{tabular}


greater with the $\mathrm{MW} / \mathrm{H}^{+} / \mathrm{H}_{2} \mathrm{O}_{2}$ or $\mathrm{MW} / \mathrm{H}^{+}$sets (Table 3). Without acid addition, phosphorus release was not significant, as indicated in sets of $\mathrm{MW}$ and $\mathrm{MW} / \mathrm{H}_{2} \mathrm{O}_{2}$. The results indicated that, in order to release considerable amounts of orthophosphate from dairy manure into solution, acid addition is required. Hydrogen peroxide would also help in augmenting phosphate release, but only slightly. Ammonia was not produced in large quantities for any of the microwave treatments. The initial ammonia concentration in solution barely increased after treatment with any chemical addition or microwave irradiation.

The MW treatment and acid addition did not increase the amounts of soluble $\mathrm{K}$ and $\mathrm{Na}$, since most of these ions were soluble in solution. The acid addition would help solubilize calcium from dairy manure; the higher soluble $\mathrm{Ca}$ concentrations were in the $\mathrm{MW} / \mathrm{H}+$ and $\mathrm{MW} / \mathrm{H}^{+} / \mathrm{H}_{2} \mathrm{O}_{2}$. Soluble magnesium ion also increased with acid addition and MW treatment (Table 3). The results indicated that, for dairy manure, hydrogen ion concentration and hydrogen peroxide dosage affected the extent of SCOD and ortho-P release, as well as calcium and magnesium in the treated solution.

\subsection{Anaerobic Biodegradability}

As noted in the earlier section, the SCOD concentration increased for all of microwave treatments, regardless of treatment conditions (Table 3). However, some of degradation products from the MW treatment constituted in SCOD could act as potential inhibitors for anaerobic digestion. For acid hydrolysis of biomass such as the $\mathrm{MW} / \mathrm{H}^{+}$, anaerobic inhibitory by-products of fufural, hydroxymethyl furfural, formic acid and levulinic acid are produced [13]. For the MW treatment of dairy manure, with or without hydrogen peroxide, phenol, aldehydes and ketones are produced, which are known to suppress anaerobic digestion [13-15]. The extent of inhibition of organic compounds affecting anaerobic digestion is dependent on toxicant concentration, biomass concentration, acclimation, and temperature [16].

The $\mathrm{pH}$ of the microwave treated solution was out of the optimal anaerobic digestion range of 6.8 - 7.4 (Table 3). Therefore, adjustment of $\mathrm{pH}$ with either sulfuric acid or sodium hydroxide for the treated solution was required, before digestion. The alkalinity addition, prior to anaerobic digestion, was also needed for the $\mathrm{MW} / \mathrm{H}^{+}$and $\mathrm{MW} / \mathrm{H}^{+} / \mathrm{H}_{2} \mathrm{O}_{2}$. While using sulfuric acid for $\mathrm{pH}$ adjustment, sulfate was introduced into the sets, either before microwave treatment or prior to anaerobic digestion. Sulfate is reduced to sulfite by the sulfate reducing bacteria (SRB) in anaerobic digestion. Sulfite is toxic to various bacterial groups, thus inhibiting methane production $[17,18]$. In the anaerobic digestion process, the SRB may compete with methanogens for common organic and inorganic substrates, thereby suppressing methane production. The use of sodium hydroxide for $\mathrm{pH}$ and sodium bicarbonate $\left(\mathrm{NaHCO}_{3}\right)$ for alkalinity adjustment would result in increased salt toxicity. The salt toxicity of anaerobic digestion was found to be mostly determined by the content of metal ions, particularly, light weight metal ions of $\mathrm{Na}, \mathrm{K}, \mathrm{Mg}, \mathrm{Ca}$ and $\mathrm{Al}$. These ions are required for microbial growth, and consequently affect specific growth rates like any other nutrient. Moderate ion concentrations stimulate microbial growth, while excessive amounts slow down the growth, and/or cause inhibition [13].

Dairy manure contains high ammonia concentration, which itself is a potential inhibitor to anaerobic digestion. Ammonia, not ammonium ion, is the main cause of inhibition. It was suggested that the extent of ammonia inhibition was affected by ammonia concentration, $\mathrm{pH}$, temperature, presence of other ions and acclimation period [13]. An increase in $\mathrm{pH}$ increases the ratio of ammonia to ammonium ion resulting in an increase in toxicity at higher $\mathrm{pH}$ ranges. A wide range of inhibiting ammonia concentrations reported in literature may be attributed to the differences in substrates and inoculum, environmental conditions and acclimation period $[19,20]$. Anaerobic digestion of wastes with a high ammonia concentration was more easily inhibited and less stable at thermophilic temperatures than at mesophilic temperatures $[21,22]$. An increase in methane yield was observed when the operating temperature was decreased from $60^{\circ} \mathrm{C}$ to $37^{\circ} \mathrm{C}$, in an anaerobic digester fed with a high ammonia concentration [23,24]. Reducing $\mathrm{pH}$ from 7.5 to 7.0 during thermophilic anaerobic digestion of cow manure also increased the methane production by four times [25].

Chemical characteristics of substrates, before and after anaerobic digestion, are presented in Tables $\mathbf{4}$ and $\mathbf{5}$. The concentration of ammonia nitrogen increased after the digestion for both digestion conditions $\left(35^{\circ} \mathrm{C}\right.$ and $\left.55^{\circ} \mathrm{C}\right)$. However, an increase in ammonia was more pronounced at $55^{\circ} \mathrm{C}$. During thermophilic digestion, high $\mathrm{pH}$ combined with high ammonia concentration would increase ammonia toxicity resulting in a lower methane yield. Higher methane production was observed when less total VFA concentration was in the resulting solution. Accumulation of propionic, butyric and isobutyric concentration occurred in the sets with high VFA concentration; they were inhibitory to the methanogens. For mesophilic digestion at $35^{\circ} \mathrm{C}$, the untreated dairy manure, MW and $\mathrm{MW} / \mathrm{H}_{2} \mathrm{O}_{2}$ had low VFA concentrations, while the $\mathrm{MW} / \mathrm{H}^{+} / \mathrm{H}_{2} \mathrm{O}_{2}$ and $\mathrm{MW} / \mathrm{H}^{+}$had substantial amounts of VFA in the digested solutions (Table 5). For thermophilic digestion, the untreated manure set had very low VFA concentration after the digestion, whereas the sets with various MW treatments gave high VFA concen- 
Table 4. Chemical characteristics of substrates before and after mesophilic digestion $\left(35^{\circ} \mathrm{C}\right)$.

\begin{tabular}{|c|c|c|c|c|c|}
\hline & Untreated & MW & $\mathrm{MW} / \mathrm{H}_{2} \mathrm{O}_{2}$ & $\mathrm{MW} / \mathrm{H}^{+}$ & $\mathrm{MW} / \mathrm{H}^{+} / \mathrm{H}_{2} \mathrm{O}_{2}$ \\
\hline \multicolumn{6}{|l|}{ Before } \\
\hline TS (\%) & $3.02 \pm 0.09$ & $2.27 \pm 0.17$ & $2.28 \pm 0.23$ & $4.08 \pm 0.08$ & $3.94 \pm 0.45$ \\
\hline VS ( $\%$ & $2.00 \pm 0.07$ & $1.48 \pm 0.116$ & $1.48 \pm 0.15$ & $2.10 \pm 0.05$ & $1.96 \pm 0.25$ \\
\hline $\operatorname{TCOD}(\mathrm{g} / \mathrm{L})$ & $31.4 \pm 6.33$ & $27.1 \pm 2.01$ & $26.5 \pm 2.28$ & $33.9 \pm 0.87$ & $32.5 \pm 5.19$ \\
\hline $\operatorname{SCOD}(\mathrm{g} / \mathrm{L})$ & $9.08 \pm 0.19$ & $9.20 \pm 0.48$ & $9.37 \pm 0.67$ & $8.4 \pm 0.29$ & $10.7 \pm 0.86$ \\
\hline VFA (mg/L) & $4384 \pm 858$ & $3157 \pm 431$ & $3427 \pm 698$ & $2669 \pm 459$ & $2766 \pm 295$ \\
\hline TP-total (mg/L) & $184 \pm 10$ & $178 \pm 15$ & $167 \pm 19$ & $266 \pm 21$ & $294 \pm 45$ \\
\hline TP-soluble (mg/L) & $8 \pm 1$ & $20 \pm 3$ & $24 \pm 3$ & $29 \pm 4$ & $58 \pm 5$ \\
\hline $\mathrm{PO}_{4}(\mathrm{mg} / \mathrm{L})$ & $8 \pm 2$ & $8 \pm 2$ & $10 \pm 3$ & $42 \pm 2$ & $15 \pm 1$ \\
\hline TKN- total (mg/L) & $1831 \pm 440$ & $1796 \pm 80$ & $1704 \pm 329$ & $1768 \pm 167$ & $1757 \pm 270$ \\
\hline $\mathrm{NH}_{4}(\mathrm{mg} / \mathrm{L})$ & $864 \pm 58$ & $689 \pm 6$ & $610 \pm 47$ & $898 \pm 15$ & $798 \pm 53$ \\
\hline $\mathrm{pH}$ & 7.6 & 7.6 & 7.6 & 7.6 & 7.8 \\
\hline TS (\%) & $2.22 \pm 0.08$ & $1.69 \pm 0.12$ & $1.66 \pm 0.13$ & $3.51 \pm 0.08$ & $3.25 \pm 0.33$ \\
\hline VS (\%) & $1.18 \pm 0.05$ & $0.92 \pm 0.07$ & $0.92 \pm 0.08$ & $1.85 \pm 0.06$ & $1.53 \pm 0.16$ \\
\hline $\mathrm{TCOD}(\mathrm{g} / \mathrm{L})$ & $20.1 \pm 0.98$ & $15.1 \pm 1.08$ & $15.4 \pm 0.88$ & $30.8 \pm 1.32$ & $31.2 \pm 4.74$ \\
\hline $\operatorname{SCOD}(\mathrm{g} / \mathrm{L})$ & $3.02 \pm 0.15$ & $3.89 \pm 0.16$ & $3.66 \pm 0.34$ & $11.0 \pm 1.07$ & $11.3 \pm 0.87$ \\
\hline VFA (mg/L) & $38 \pm 10$ & $10 \pm 3$ & $0 \pm 0$ & $1885 \pm 484$ & $1955 \pm 192$ \\
\hline TP-total (mg/L) & $295 \pm 19$ & $232 \pm 24$ & $241 \pm 57$ & $282 \pm 6$ & $280 \pm 48$ \\
\hline TP-soluble (mg/L) & $2.0 \pm 1$ & $23 \pm 1$ & $32 \pm 9$ & $8 \pm 2$ & $22 \pm 2$ \\
\hline $\mathrm{PO}_{4}(\mathrm{mg} / \mathrm{L})$ & $10 \pm 1$ & $20 \pm 1$ & $24 \pm 1$ & $19 \pm 3$ & $22 \pm 1$ \\
\hline TKN- total (mg/L) & $2057 \pm 112$ & $1884 \pm 69$ & $1649 \pm 170$ & $1770 \pm 66$ & $1617 \pm 336$ \\
\hline $\mathrm{NH}_{4}(\mathrm{mg} / \mathrm{L})$ & $1198 \pm 22$ & $1117 \pm 16$ & $985 \pm 19$ & $1266 \pm 29$ & $1050 \pm 83$ \\
\hline $\mathrm{pH}$ & 7.5 & 7.8 & 7.7 & 7.6 & 7.5 \\
\hline
\end{tabular}

Table 5. Chemical characteristics of substrates before and after thermophilic digestion $\left(55^{\circ} \mathrm{C}\right)$.

\begin{tabular}{|c|c|c|c|c|c|}
\hline & Untreated & MW & $\mathrm{MW} / \mathrm{H}_{2} \mathrm{O}_{2}$ & $\mathrm{MW} / \mathrm{H}^{+}$ & $\mathrm{MW} / \mathrm{H}^{+} / \mathrm{H}_{2} \mathrm{O}_{2}$ \\
\hline \multicolumn{6}{|l|}{ Before } \\
\hline TS $(\%)$ & $3.72 \pm 0.03$ & $3.61 \pm 0.14$ & $3.52 \pm 0.12$ & $4.60 \pm 0.07$ & $4.31 \pm 0.46$ \\
\hline VS $(\%$ & $2.44 \pm 0.02$ & $2.42 \pm 0.10$ & $2.33 \pm 0.09$ & $2.44 \pm 0.04$ & $2.18 \pm 0.26$ \\
\hline $\mathrm{TCOD}(\mathrm{g} / \mathrm{L})$ & $40.3 \pm 2.30$ & $38.0 \pm 2.77$ & $36.9 \pm 0.82$ & $38.1 \pm 0.52$ & $34.1 \pm 4.58$ \\
\hline $\mathrm{SCOD}(\mathrm{g} / \mathrm{L})$ & $10.9 \pm 0.21$ & $10.2 \pm 0.50$ & $10.6 \pm 0.21$ & $9.59 \pm 0.09$ & $9.87 \pm 1.07$ \\
\hline VFA (mg/L) & $3802 \pm 94$ & $3292 \pm 88$ & $3249 \pm 66$ & $2755 \pm 106$ & $1733 \pm 434$ \\
\hline TP-total (mg/L) & $408 \pm 28$ & $373 \pm 30$ & $403 \pm 19$ & $421 \pm 15$ & $380 \pm 48$ \\
\hline TP-soluble (mg/L) & $35 \pm 5$ & $21 \pm 3$ & $26 \pm 10$ & $65 \pm 3$ & $68 \pm 9$ \\
\hline $\mathrm{PO}_{4}(\mathrm{mg} / \mathrm{L})$ & $22 \pm 3$ & $6 \pm 1$ & $8 \pm 2$ & $51 \pm 3$ & $39 \pm 5$ \\
\hline TKN- total (mg/L) & $2907 \pm 206$ & $2505 \pm 201$ & $2638 \pm 69$ & $2989 \pm 82$ & $2556 \pm 297$ \\
\hline $\mathrm{NH}_{4}(\mathrm{mg} / \mathrm{L})$ & $1043 \pm 15$ & $845 \pm 21$ & $728 \pm 8$ & $937 \pm 44$ & $707 \pm 58$ \\
\hline $\mathrm{pH}$ & 7.3 & 7.4 & 7.3 & 7.1 & 7.3 \\
\hline \multicolumn{6}{|l|}{ After } \\
\hline TS (\%) & $2.95 \pm 0.03$ & $3.09 \pm 0.12$ & $3.09 \pm 0.10$ & $4.00 \pm 0.08$ & $3.81 \pm 0.42$ \\
\hline VS (\%) & $1.68 \pm 0.02$ & $1.97 \pm 0.08$ & $1.96 \pm 0.05$ & $2.00 \pm 0.05$ & $1.84 \pm 0.23$ \\
\hline $\mathrm{TCOD}(\mathrm{g} / \mathrm{L})$ & $23.1 \pm 0.19$ & $28.9 \pm 0.90$ & $27.7 \pm 1.20$ & $32.3 \pm 1.02$ & $29.6 \pm 5.47$ \\
\hline $\operatorname{SCOD}(\mathrm{g} / \mathrm{L})$ & $5.30 \pm 0.32$ & $10.3 \pm 0.24$ & $11.3 \pm 0.81$ & $11.9 \pm 0.45$ & $11.0 \pm 1.53$ \\
\hline VFA (mg/L) & $271 \pm 30$ & $3069 \pm 154$ & $3002 \pm 188$ & $3073 \pm 176$ & $2649 \pm 259$ \\
\hline TP-total (mg/L) & $388 \pm 22$ & $339 \pm 23$ & $337 \pm 22$ & $333 \pm 9$ & $311 \pm 29$ \\
\hline TP-soluble (mg/L) & $11 \pm 4$ & $38 \pm 7$ & $37 \pm 2$ & $21 \pm 1$ & $29 \pm 6$ \\
\hline $\mathrm{PO}_{4}(\mathrm{mg} / \mathrm{L})$ & $9 \pm 2$ & $23 \pm 4$ & $21 \pm 1$ & $11 \pm 1$ & $17 \pm 1$ \\
\hline TKN- total (mg/L) & $2225 \pm 165$ & $2049 \pm 41$ & $1893 \pm 89$ & $2485 \pm 66$ & $2036 \pm 229$ \\
\hline $\mathrm{NH}_{4}(\mathrm{mg} / \mathrm{L})$ & $1357 \pm 22$ & $1209 \pm 16$ & $1052 \pm 9$ & $1325 \pm 9$ & $1118 \pm 96$ \\
\hline $\mathrm{pH}$ & 7.8 & 7.6 & 7.6 & 7.5 & 7.4 \\
\hline
\end{tabular}


trations. Accumulation of VFA would lead to a decrease in $\mathrm{pH}$, thereby reducing ammonia concentration.

The interaction between ammonia, VFA and $\mathrm{pH}$ may lead to an "inhibited steady state", a condition where the process is running steady, but with a lower methane production $[26,27]$. It seemed that most of the MW treatments were in "inhibited steady state" conditions in this study.

The cumulative methane production profiles are presented in Figures 1-3. The untreated manure sets $\left(35^{\circ} \mathrm{C}\right.$ and $55^{\circ} \mathrm{C}$ ) showed higher methane yield (litre methane production per gram of volatile solid added, or litre methane production per gram of volatile solid destroyed) than the MW treated manures (Table 6). At $35^{\circ} \mathrm{C}$, the MW and the $\mathrm{MW} / \mathrm{H}_{2} \mathrm{O}_{2}$ treatment had similar methane yield compared to the untreated manure, while, lower methane yields were obtained for the $\mathrm{MW} / \mathrm{H}^{+}$and $\mathrm{MW} / \mathrm{H}^{+} / \mathrm{H}_{2} \mathrm{O}_{2}$. All MW treatments decreased methane yield in anaerobic digestion at $55^{\circ} \mathrm{C}$. Methane yields for the MW and the $\mathrm{MW} / \mathrm{H}_{2} \mathrm{O}_{2}$ at $55^{\circ} \mathrm{C}$ were only one third of their counterparts at $35^{\circ} \mathrm{C}$. A higher methane yield was obtained for the MW treatment without acid addition than the one with acid addition. There was no severe inhibition for the MW and the $\mathrm{MW} / \mathrm{H}_{2} \mathrm{O}_{2}$ treatment at $35^{\circ} \mathrm{C}$, while severe inhibition was observed for the $\mathrm{MW} / \mathrm{H}^{+}$and $\mathrm{MW} / \mathrm{H}^{+} / \mathrm{H}_{2} \mathrm{O}_{2}$ at $35^{\circ} \mathrm{C}$. At $55^{\circ} \mathrm{C}$, all MW treatments had some degree of inhibition, attributed mainly to ammonia toxicity. Although an increase in process temperature will have a positive effect on the metabolic rate of the microorganisms, it also results in a higher concentration of free ammonia in the solution, resulting in ammonia toxicity. However, the microbial inhibition in treated manure might be due to a combination of several factors: the competition of SRB with methanogens to utilize common organic compounds, toxicity of salts such as $\mathrm{K}$, $\mathrm{Na}, \mathrm{Ca}$, and $\mathrm{Mg}$, organic inhibitors produced in the MW pretreatment and high concentration of ammonia in the solution.

Some researchers have investigated the effects of various inhibitors on methane production [28-30]. Jin, et al. [28] reported that microwave heating $\left(120^{\circ} \mathrm{C}\right)$ combined with different chemicals $\left(\mathrm{NaOH}, \mathrm{CaO}, \mathrm{H}_{2} \mathrm{SO}_{4}\right.$ or $\mathrm{HCl}$ ) enhanced solubilization of manure particulates and degradation of glucan/xylan in dairy manure. Acid hydrolysis $\left(\mathrm{MW} / \mathrm{H}^{+}\right)$had a higher ratio of SCOD/TCOD than base hydrolysis $\left(\mathrm{MW} / \mathrm{OH}^{-}\right)$, and a much higher ratio of SCOD/TCOD was seen for the MW/ $/ \mathrm{H}^{+}$than for the $\mathrm{MW} / \mathrm{H}^{+} / \mathrm{H}_{2} \mathrm{O}_{2}$ treatment in their study. When sulfuric acid was used for the $\mathrm{MW} / \mathrm{H}^{+}$pretreatment, the methane production was lower than raw dairy manure.

For MW pretreatment with $\mathrm{HCl}$, the methane produc tion was better than with $\mathrm{H}_{2} \mathrm{SO}_{4}$, although methane production decreased to some extent compared to raw manure. It is also interesting to note that MW heating of dairy manure produced more methane than the conventional heating methods, in their study [28].

Quao et al. [29] reported that using conventional heating method $\left(170^{\circ} \mathrm{C}\right.$ at $\left.1 \mathrm{~h}\right)$, methane yield increased

Table 6. Cumulative methane production rate, maximum methane production and yield for dairy manure.

\begin{tabular}{|c|c|c|c|c|c|c|}
\hline \multirow[t]{2}{*}{ Set } & \multicolumn{3}{|c|}{ Modified Gompertz Equation (model) } & \multicolumn{3}{|c|}{ Experimental data } \\
\hline & $\begin{array}{l}\text { Methane production } \\
\text { potential, } \mathrm{A} \\
\left(\mathrm{mL} \mathrm{CH}_{4}\right)\end{array}$ & $\begin{array}{l}\text { Maximum methane } \\
\text { production rate, } \mathrm{U} \\
\left(\mathrm{mL} \mathrm{CH}_{4} / \mathrm{g} \mathrm{VS} / \text { day }\right)\end{array}$ & Lag time, $\lambda(\mathrm{d})$ & $\mathrm{r}^{\mathrm{a}}$ & $\begin{array}{l}\text { Methane yield per } \\
\text { VS added } \\
(\mathrm{mL} \mathrm{CH} / \mathrm{g} \mathrm{VS})\end{array}$ & $\begin{array}{c}\text { Methane yield per VS } \\
\text { destroyed }\left(\mathrm{mL} \mathrm{CH}_{4} / \mathrm{g} \mathrm{VS}\right)\end{array}$ \\
\hline \multicolumn{7}{|l|}{$35^{\circ} \mathrm{C}$} \\
\hline Untreated & $493 \pm 17$ & $10.9 \pm 0.6$ & $7.18 \pm 0.13$ & 0.994 & $265 \pm 13$ & $584 \pm 40$ \\
\hline MW & $270 \pm 23$ & $7.8 \pm 0.9$ & $7.19 \pm 0.25$ & 0.986 & $213 \pm 24$ & $517 \pm 70$ \\
\hline $\mathrm{MW} / \mathrm{H}_{2} \mathrm{O}_{2}$ & $272 \pm 14$ & $8.4 \pm 0.9$ & $7.23 \pm 0.09$ & 0.985 & $218 \pm 27$ & $521 \pm 79$ \\
\hline $\mathrm{MW} / \mathrm{H}^{+}$ & $110 \pm 6$ & $3.4 \pm 0.2$ & $5.86 \pm 0.19$ & 0.987 & $52 \pm 3$ & $391 \pm 24$ \\
\hline $\mathrm{MW} / \mathrm{H}^{+} / \mathrm{H}_{2} \mathrm{O}_{2}$ & $141 \pm 57$ & $2.8 \pm 0.9$ & $6.52 \pm 1.55$ & 0.959 & $51 \pm 11$ & $213 \pm 51$ \\
\hline \multicolumn{7}{|l|}{$55^{\circ} \mathrm{C}$} \\
\hline Untreated & $447 \pm 24$ & $16.7 \pm 1.1$ & $1.51 \pm 0.04$ & 0.938 & $199 \pm 10$ & $460 \pm 24$ \\
\hline MW & $233 \pm 14$ & $20.2 \pm 1.6$ & $0.26 \pm 0.03$ & 0.983 & $94 \pm 7$ & $292 \pm 25$ \\
\hline $\mathrm{MW} / \mathrm{H}_{2} \mathrm{O}_{2}$ & $229 \pm 8$ & $21.3 \pm 1.4$ & $0.07 \pm 0.01$ & 0.982 & $95 \pm 6$ & $329 \pm 20$ \\
\hline $\mathrm{MW} / \mathrm{H}^{+}$ & $154 \pm 6$ & $19.2 \pm 0.9$ & $0.18 \pm 0.02$ & 0.979 & $70 \pm 3$ & $227 \pm 10$ \\
\hline $\mathrm{MW} / \mathrm{H}^{+} / \mathrm{H}_{2} \mathrm{O}_{2}$ & $134 \pm 6$ & $16.4 \pm 2.0$ & $0.14 \pm 0.03$ & 0.980 & $70 \pm 10$ & $247 \pm 44$ \\
\hline
\end{tabular}

a correlation coefficient. 


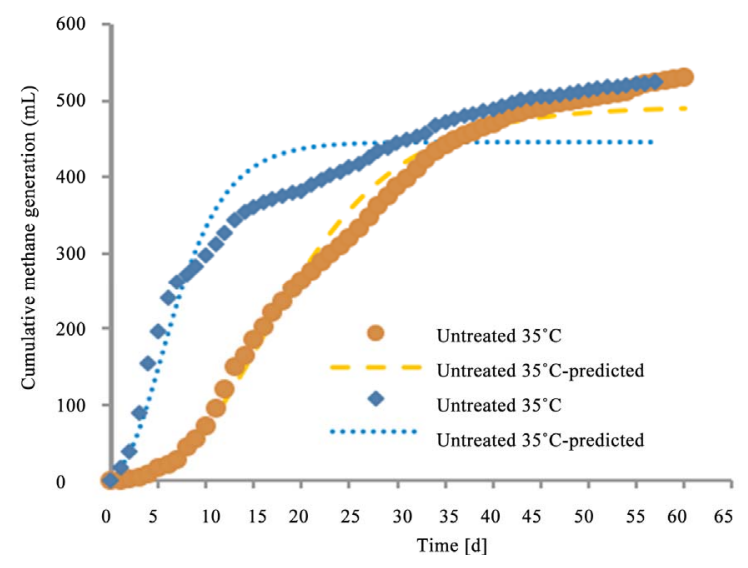

Figure 1. Cumulative methane production profile for untreated manure sets at $35^{\circ} \mathrm{C}$ and $55^{\circ} \mathrm{C}$.

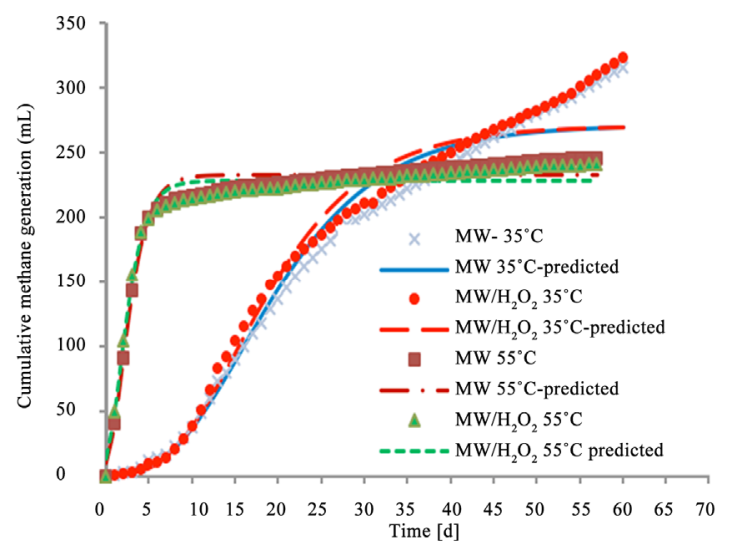

Figure 2. Cumulative methane production profile for $\mathrm{MW}$ and $\mathrm{MW} / \mathrm{H}_{2} \mathrm{O}_{2}$ treated manure sets at $35^{\circ} \mathrm{C}$ and $55^{\circ} \mathrm{C}$.

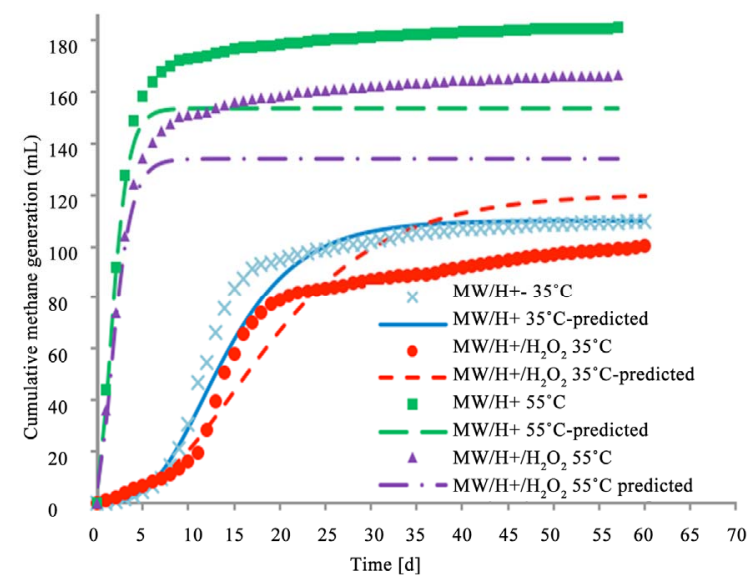

Figure 3. Cumulative methane production profile for $\mathrm{MW} / \mathrm{H}^{+}$and $\mathrm{MW} / \mathrm{H}^{+} / \mathrm{H}_{2} \mathrm{O}_{2}$ treated manure sets at $35^{\circ} \mathrm{C}$ and $55^{\circ} \mathrm{C}$.

for pig manure and sewage waste, while methane yield for treated dairy manure decreased by $6.9 \%$, compared to the untreated dairy manure. Anaerobic biodegradability of cattle manure was also studied, using conventional heat pretreatment at temperatures between $100^{\circ} \mathrm{C}$ and $225^{\circ} \mathrm{C}$ for 15 minutes [30].

The treatment showed a significant improvement in its biochemical methane potential of $13 \%$ at $175^{\circ} \mathrm{C}$ and $21 \%$ at $200^{\circ} \mathrm{C}$, but its methane potential decreased about $10 \%$ at $100^{\circ} \mathrm{C}$, compared to the untreated manure.

These studies strengthen our assertions that various inhibitors formed during the pretreatment processes, suppress methane production. Pretreatment of dairy manure at temperatures below $100^{\circ} \mathrm{C}$ and addition of acid would decrease methane production. The results from this study also indicated that sulfuric acid was not suitable for $\mathrm{pH}$ adjustment in the pretreatment process; acid was not required for the pretreatment of dairy manure for enhancing methane production; and the $\mathrm{MW}$ and $\mathrm{MW} /$ $\mathrm{H}_{2} \mathrm{O}_{2}$ pretreatment of dairy manure enhanced solubilization of particulates, but did not enhance methane production.

The kinetic data obtained from the anaerobic digestion experiments were examined for the fitness of modified Gompertz equation [31]. The modified Gompertz equation is stated as following:

$$
P=A \exp \left\{-\exp \left[\frac{U e}{A}(\lambda-t)+1\right]\right\}
$$

where, $P$ is cumulative specific methane production, $\mathrm{mL} / \mathrm{g}$ VS; $A$ is methane production potential, $\mathrm{mL}$; $U$ is maximum methane production rate, $\mathrm{mL} / \mathrm{g}$ VS day; $\lambda$ is lag phase period (minimum time to produce methane), day; and $t$ is cumulative time for methane production, day.

Methane production potential is based on the assumption that the methane production rate in a batch condition, corresponds to specific growth rate of microorganisms in the bioreactor. The kinetic constants of $U, A$, and $\lambda$ can, therefore, be determined using non-linear regression.

The modified Gompertz equation fitted well the experimental data for anaerobic digestion kinetics for both mesophilic and thermophilic conditions, as showed in Figures 1-3. The estimated values of the parameters $(U$, $A$ and $\lambda$ ) obtained are summarized in Table 6. The methane production rate $(U)$ was higher for thermophilic digestion at $55^{\circ} \mathrm{C}$ than for mesophilic digestion at $35^{\circ} \mathrm{C}$. An increase in process temperature increased the metabolic rate of the microorganisms; as a result, thermophilic digestion had a higher total methane production rate. Even though a higher methane production rate was obtained at $55^{\circ} \mathrm{C}$, methane yield, in terms of methane production per volatile solids added, was lower (Table 6). A lower yield was attributed to the inhibition caused by changes in $\mathrm{pH}$, ammonia and VFA concentration. As discussed earlier, ammonia concentration inhibited digestion at thermophilic temperatures than at mesophilic temperatures $[21,22]$.

Methane production potentials for the untreated ma- 
nure sets were $493 \mathrm{~mL} \mathrm{CH}_{4}$ at $55^{\circ} \mathrm{C}$ and $452 \mathrm{~mL} \mathrm{CH}_{4}$ at $35^{\circ} \mathrm{C}$. Methane production potential $(A)$ decreased for all of the MW treatment sets, regardless of treatment conditions. The results from this study implied that, microwave treatment of dairy manure increased soluble organic compounds, but they did not improve methane production. Therefore, both methane potential and rate decreased for the sets of MW pretreatment. Studying kinetics of biogas production from cattle manure, Budiyono et al. [31] reported that $A, U$ and $\lambda$ for whole manure digested at $38.5^{\circ} \mathrm{C}$ were $136.6 \mathrm{~mL}$ biogas $/ \mathrm{g}$ VS, 5.68 $\mathrm{mL}$ biogas/g VS'd and $14.75 \mathrm{~d}$, respectively. Adiga et al. [32] reported a methane production potential, $A$ of 245.1 $\mathrm{mL} \mathrm{CH}_{4}, U$ of $7.4 \mathrm{~mL} \mathrm{CH} / \mathrm{g}$ VS'd and $\lambda$ of $10.7 \mathrm{~d}$ for cow manure digested at $35^{\circ} \mathrm{C}$. Methane yield for cow manure was reported as $230 \mathrm{~mL} \mathrm{CH} / \mathrm{g}$ VS added. Gomez et al. reported a methane yield of $234 \pm 19$ and 159 $\pm 17 \mathrm{~mL} / \mathrm{g}$ VS added, for mesophilic and thermophilic digesters, respectively for cattle manure [33]. The results of the untreated manure sets in this study were comparable to their findings.

Anaerobic digestion of MW pre-treated sewage sludge (MW and $\mathrm{MW} / \mathrm{H}_{2} \mathrm{O}_{2}$ ) was carried out to examine the effect of substrate on methane yield. The VS contents for aerobic sludge, $\mathrm{MW}$ and $\mathrm{MW} / \mathrm{H}_{2} \mathrm{O}_{2}$ treated sludge were $0.52 \%, 0.53 \%$ and $0.51 \%$, respectively. The laboratory experiments and chemical analyses were conducted in the same manner as that for dairy manure. The values of methane yield per VS added and per VS destroyed for all sets of sewage sludge were comparable with those of dairy manure. The kinetic constants obtained from Gompertz Equation for sewage sludge were higher for the treated sets when compared to their control under both mesophilic and thermophilic conditions (Table 7).
However, the methane production potentials of the sewage sludge sets were lower than that of dairy manure, which can be attributed to the low content of TS in the sewage sludge used; a higher TS content may have resulted in higher methane yields. The maximum methane production rates of the pre-treated sludge under mesophilic and thermophilic conditions were greater than that of their respective controls, indicating no inhibition. However, the rates under thermophilic condition were lower than their mesophilic counterparts. This could be due to lack of acclimatization of inoculum to the presence of the substrate under thermophilic conditions, but the exact reasons for such behavior are not clear. In general, the MW and $\mathrm{MW} / \mathrm{H}_{2} \mathrm{O}_{2}$ pre-treatments improved methane production for sewage sludge; although, it did not have major impacts for methane production for dairy manure. The results from the anaerobic digestion study indicate that the benefits of the $\mathrm{MW}$ and $\mathrm{MW} / \mathrm{H}_{2} \mathrm{O}_{2}$ pre-treatment for anaerobic digestion are substrate-specific.

\section{Summary and Conclusions}

Liquid-solids separation of raw dairy manure resulted in solid fractions richer in TS and liquid fractions richer in nutrients and metal ions. The manure with 1:1 dilution was best for the purpose of nutrient release and solids solubilization. The release of orthophosphate was greater with the $\mathrm{MW} / \mathrm{H}^{+}$and $\mathrm{MW} / \mathrm{H}^{+} / \mathrm{H}_{2} \mathrm{O}_{2}$ treatment. The SCOD values increased in the case of all of the MW treatment conditions, while it decreased with an addition of acid without MW treatment.

Anaerobic digestion of liquid manure, without microwave treatment, outperformed the sets with microwave treatment. The microwave-treated liquid dairy manure,

Table 7. Cumulative methane production rate, maximum methane production and yield for aerobic sludge.

\begin{tabular}{|c|c|c|c|c|c|c|}
\hline \multirow[t]{2}{*}{ Set } & \multicolumn{3}{|c|}{ Modified Gompertz Equation (model) } & & \multicolumn{2}{|c|}{ Experimental data } \\
\hline & $\begin{array}{l}\text { Methane production } \\
\text { potential, } \mathrm{A} \\
\left(\mathrm{mL} \mathrm{CH}_{4}\right)\end{array}$ & $\begin{array}{l}\text { Maximum methane } \\
\text { production rate, } \mathrm{U} \\
\left(\mathrm{mL} \mathrm{CH}_{4} / \mathrm{g} \mathrm{VS} / \text { day }\right)\end{array}$ & Lag time, $\lambda(\mathrm{d})$ & $\mathrm{r}^{\mathrm{a}}$ & $\begin{array}{c}\text { Methane yield per } \\
\text { VS added } \\
\left(\mathrm{mL} \mathrm{CH}_{4} / \mathrm{g} \mathrm{VS}\right)\end{array}$ & $\begin{array}{c}\text { Methane yield per VS } \\
\text { destroyed }\left(\mathrm{mL} \mathrm{CH}_{4} / \mathrm{g} \mathrm{VS}\right)\end{array}$ \\
\hline \multicolumn{7}{|l|}{$35^{\circ} \mathrm{C}$} \\
\hline MW & $123 \pm 3$ & $19.1 \pm 1.2$ & $0.76 \pm 0.13$ & 0.999 & $238 \pm 7$ & $609 \pm 18$ \\
\hline $\mathrm{MW} / \mathrm{H}_{2} \mathrm{O}_{2}$ & $116 \pm 3$ & $19.6 \pm 0.4$ & $0.92 \pm 0.08$ & 0.998 & $238 \pm 6$ & $620 \pm 19$ \\
\hline \multicolumn{7}{|l|}{$55^{\circ} \mathrm{C}$} \\
\hline Control & $137 \pm 11$ & $8.1 \pm 1.2$ & $2.60 \pm 0.62$ & 0.992 & $155 \pm 14$ & $555 \pm 55$ \\
\hline $\mathrm{MW} / \mathrm{H}_{2} \mathrm{O}_{2}$ & $127 \pm 4$ & $8.3 \pm 0.8$ & $1.71 \pm 0.19$ & 0.998 & $156 \pm 6$ & $407 \pm 34$ \\
\hline
\end{tabular}

${ }^{\mathrm{a}}$ correlation coefficient. 
without acid addition, had better results in terms of methane potential and methane production than with acid addition. Thermophilic digestion exhibited higher maximum methane production rates than that of mesophilic digestion, but methane yields in terms of yield per volatile solids added or destroyed were lower.

\section{Acknowledgements}

The authors wish to acknowledge research funding from Agriculture and Agri-Food Canada thorough the Advancing Canadian Agriculture and Agri-Food (ACAAF) program. We wish to acknowledge the support of the following organizations for making this project possible: The Investment Agriculture Foundation of British Columbia, the New Brunswick Agricultural Council, the Prince Edward Island ADAPT Council, Agri-Futures Nova Scotia, the Newfoundland and Labrador AgriAdapt Council, the Community Development Council of Saskatchewan and the Manitoba Rural Adaptation Council. AAFC is pleased to participate in the production of this publication. AAFC is committed to working with our industry partners and the Investment Agriculture Foundation of $\mathrm{BC}$ to increase public awareness of the importance of the agriculture and agri-food industry to Canada. Opinions expressed in this publication are those of University of British Columbia and not necessarily AAFC's.

\section{REFERENCES}

[1] C. Rico, H. Garcia and J. L. Rico, "Physical-AnaerobicChemical Process for Treatment of Dairy Manure," Bioresource Technology, Vol. 102, No. 3, 2011, pp. 21432150. doi:10.1016/j.biortech.2010.10.068

[2] K. V. Lo, N. R. Bulley, P. H. Liao and A. J. Whitehead, "The Effect of Solids-Separation Pretreatment on Biogas Production from Dairy Manure," Agricultural Wastes, Vol. 8, No. 3, 1983, pp. 155-165. doi:10.1016/0141-4607(83)90114-2

[3] K. V. Lo and P. H. Liao, "Methane Production Using a Whole and Screened Dairy Manure in Conventional and Fixed-Film Reactors," Biotechnology Bioengineering, Vol. 27, No. 3, 1985, pp. 266-272. doi:10.1002/bit.260270309

[4] C. Rico, H. Garcia, J. L. Rico and I. Tejero, "Characterisation of Solid and Liquid Fractions of Dairy Manure with Regard to Their Component Distribution and Methane Production," Bioresource Technology, Vol. 98, No. 5, 2007, pp. 971-979. doi:10.1016/j.biortech.2006.04.032

[5] W. I. Chan, P. H. Liao and K. V. Lo, "Effects of Irradiation Intensity and $\mathrm{pH}$ on Nutrients Release and Solids Destruction of Waste Activated Sludge Using the Microwave Enhanced Advanced Oxidation Process," Water Environment Research, Vol. 82, No. 11, 2010, pp. 22292238. doi:10.2175/106143010X12681059116419

[6] A. Kenge, P. H. Liao and K. V. Lo, "Treating Solid Dairy
Manure Using Microwave-Enhanced Advanced Oxidation Process," Journal of Environmental Science and Health, Part-B, Vol. 44, No. 6, 2009, pp. 606-612. doi:10.1080/03601230903000693

[7] P. H. Liao, K. V. Lo, W. I. Chan and W. T. Wong, "Sludge Reduction and Volatile Fatty Acid Recovery Using Microwave Advanced Oxidation Process," Journal of Environmental Science and Health, Part-A, Vol. 42, No. 5, 2007, pp. 633-639. doi:10.1080/10934520701244417

[8] W. T. Wong, K. V. Lo and P. H. Liao, "Factors Affecting Nutrient Solubilization from Sewage Sludge in Microwave Advanced Oxidation Process," Journal of Environmental Science and Health, Part A, Vol. 42, No. 6, 2007, pp. 825-829. doi:10.1080/10934520701304914

[9] American Public Health Association, "Standard Methods for the Examination of Water and Wastewater," 20th Edition, American Public Health Association, Washington DC, 1998.

[10] A. M. Wolf, P. A. Kleinman, A. N. Sharpley and D. B. Beegle, "Development of a Water-Extractable Phosphorus Test for Manure: An Interlaboratory Study," Soil Science Society of America Journal, Vol. 69, No. 3, 2005, pp. 695-700. doi:10.2136/sssaj2004.0096

[11] K. V. Lo and P. H. Liao, "Microwave Enhanced Advanced Oxidation in the Treatment of Diary Manure," Microwave Heating; In Tech, Open Access Publisher, Rijeka, 2011.

[12] S. K. Yawson, P. H. Liao and K. V. Lo, "Two-Stage Dilute Acid Hydrolysis of Dairy Manure for Nutrient Release, Solids Reduction and Reducing Sugar Production," Natural Resources, Vol. 2, No. 4, 2011, pp. 224-233. doi:10.4236/nr.2011.24028

[13] Y. Chen, J. J. Cheng and K. C. Creamer, "Inhibition of Anaerobic Digestion Process: A Review," Bioresource Technology, Vol. 99, No. 10, 2008, pp. 4044-4064. doi:10.1016/j.biortech.2007.01.057

[14] A. T. Quitain, M. Faisal, K. Kang, H. Daimon and K. Fujie, "Low-Molecular-Weight Carboxylic Acids Produced from Hydrothermal Treatment of Organic Wastes," Journal of Hazardous Materials, Vol. 93, No. 2, 2002, pp. 209-220. doi:10.1016/S0304-3894(02)00024-9

[15] R. Sierra-Alverez and G. Lettinga, "The Methanogenic Toxicity of Wastewater Lignin and Lignin Related Compounds," Journal of Chemical Technology and Biotechnology, Vol. 34, No. 4, 1991, pp. 443-455.

[16] J. Yang and R. E. Speece, "The Effects of Chloroform Toxicity on Methane Fermentation," Water Research, Vol. 20, No. 12, 1986, pp. 1273-1279. doi:10.1016/0043-1354(86)90158-2

[17] I. W. Koster, A. Rinzema, A. L. De Vigt and G. Lettinga, "Sulfide Inhibition of the Methanogenic Activity of Granular Sludge at Various pH Levels," Water Research, Vol. 20, No. 12, 1986, pp. 1561-1567. doi:10.1016/0043-1354(86)90121-1

[18] E. Colleran, S. Finnegan and P. Lens, "Anaerobic Treatment of Sulfate Containing Waste Streams," Antonie ven Leeuwenhoek, Vol. 67, No. 1, 1995, pp. 29-46. 
doi:10.1007/BF00872194

[19] A. G. Hashimoto, "Methane from Swine Manure: Effect of Temperature and Influent Substrate Concentration on Kinetic Parameter (k)," Agricultural Wastes, Vol. 9, No. 4, 1984, pp. 299-308. doi:10.1016/0141-4607(84)90088-X

[20] A. G. Hashimoto, "Ammonia Inhibition of Methanogensis from Cattle Wastes," Agricultural Wastes, Vol. 17, No. 4, 1986, pp. 241-261. doi:10.1016/0141-4607(86)90133-2

[21] B. Braun, P. Huber and J. Meyrath, "Ammonia Toxicity in Liquid Piggery Manure Digestion," Biotechnology Letters, Vol. 3, No. 4, 1981, pp. 159-144. doi:10.1007/BF00239655

[22] G. F. Parkin and S. W. Millar, "Response of Methane Fermentation to Continuous Addition of Selected Industrial Toxicants," Proceedings of the 37th Purdue Industrial Waste Conference, West Lafayette, 1983, pp. 729744.

[23] I. Angelidaki and B. K. Ahring, "Anaerobic Thermophilic Digestion of Manure at Different Ammonia Loads: Effect of Temperature," Water Research, Vol. 28, No. 3, 1994, pp. 727-731. doi:10.1016/0043-1354(94)90153-8

[24] K. H. Hansen, I. Angelidaki and B. K. Ahring, "Improving Thermophilic Anaerobic Digestion of Swine Manure," Water Research, 33, No. 8, 1999, pp. 1805-1810. doi:10.1016/S0043-1354(98)00410-2

[25] G. Zeeman, W. M. Wiegan, M. E. Koster-Treflers and G. Lettinga, "The Influence of the Total Ammonia Concentration on the Thermophilic Digestion of Cow Manure," Agricultural Wastes, Vol. 14, No. 1, 1985, pp. 19-35. doi:10.1016/S0141-4607(85)80014-7

[26] I. Angelidaki and B. K. Ahring, "Thermophilic Digestion of Livestock Waste: The Effect of Ammonia," Applied Microbiology and Biotechnology, Vol. 38, No. 4, 1993, pp. 560-564. doi:10.1007/BF00242955

[27] I. Angelidaki, L. Ellegarrd and B. K. Ahring, "A Mathe- matical Model for Dynamic Simulation of Anaerobic Digestion of Complex Substrates: Focusing on Ammonia Inhibition," Biotechnology Bioengineering, Vol. 42, No. 2, 1993, pp. 159-166. doi:10.1002/bit.260420203

[28] Y. Jin, Z. Hu and Z. Wen, "Enhancing Anaerobic Digestibility and Phosphorus Recovery of Dairy Manure Through Microwave-Based Thermochemical Pretreatment," Water Research, Vol. 43, No. 14, 2009, pp. 3493 3502 .

[29] W. Quao, X. Yan, J. Ye, Y. Sun, W. Wang and Z. Zhang, "Evaluation of Biogas Production from Different Biomass Waste with/without Hydrothermal Pretreatment," Renewable Energy, Vol. 36, No. 12, 2011, pp. 3313-3318. doi:10.1016/j.renene.2011.05.002

[30] C. S. Raju, S. Sutaryo, A. J. Ward and H. B. Moller, "Effects of High-Temperature Isochoric Pretreatment on the Methane Yields of Cattle, Pig and Chicken Manure," Environmental Technology, Vol. 34, No. 2, 2012, pp. 239244. doi:10.1080/09593330.2012.689482

[31] B. Budiyono, I. N. Widiasa, S. Johari and S. Sunarso, "The Kinetic of Biogas Production Rate from Cattle Manure in Batch Mode," International Journal of Chemical and Biological Engineering, Vol. 3, No. 1, 2010, pp. $39-45$.

[32] S. Adiga, R. Ramya, B. B. Shankar, H. P. Jagadish and C. R. Geetha, "Kinetics of Anaerobic Digestion of Water Hyacinth, Poultry Litter, Cow Manure and Primary Sludge: A Comparative Study," Proceedings of the 2nd International Conference on Biotechnology and Environment, Vol. 42, 2012, pp. 73-78.

[33] X. Gomez, D. Blanco, A. Lobato, A. Calleja, F. MartınezNunez and J. Martin-Villacorta, "Digestion of Cattle Manure under Mesophilic and Thermophilic Conditions: Characterization of Organic Matter Applying Thermal Analysis and 1H NMR," Biodegradation, Vol. 22, No. 3, 2011, pp. 623-635. doi:10.1007/s10532-010-9436-y 